\title{
A gyógyszerkutatás új irányzatai: hatékonyság és biztonságosság
}

\author{
Kotschy András* \\ Servier Kutatóintézet ZRt, Budapest, Magyarország \\ Beérkezett: 2021. május 5.; Elfogadva: 2021. június 8.
}

\begin{abstract}
Összefoglalás
A betegségek mögött meghúzódó biokémiai, sejtbiológiai változások molekuláris szintű megértése a korszerú gyógyszerkutatás alapját képezi. A kiválasztott biológiai célpont, leggyakrabban egy fehérje, múködésének gátlásától vagy fokozásától azt reméljük, hogy elősegíti a gyógyulást. A hagyományos gyógyszerkutatási megközelítések molekuláris alapját a kiválasztott fehérjével való közvetlen kölcsönhatás jelentette. Ugyanakkor a sejten belüli molekuláris biológiai folyamatok részletesebb megértése több új megközelítést nyitott a gyógyszerkutatás számára. A közlemény ezeket a gyógyszerkutatási irányzatokat mutatja be, külön kitérve biztonságosságukra.
\end{abstract}

Kulcsszavak: gyógyszerkutatás, hatásmechanizmus, enzimgátlás, fehérjeszint-szabályozás, személyre szabott terápia

\section{New directions in drug discovery: safety and efficiency}

\author{
András Kotschy* \\ Servier Research Institute of Medicinal Chemistry, Budapest, Hungary
}

\begin{abstract}
Summary
Human diseases originate from and are accompanied by changes in the biochemistry of cells. The molecular level understanding of these deviations from normal functioning is key to the curing of the diseases, therefore a principal objective of drug discovery. The key-lock principle postulated by Emil Fischer serves well the understanding of most enzymatic processes and has been helping researchers both in academia and industry to discover new drugs. The binding of a small molecule to the target protein and inhibiting or activating its function is the basis for the efficient functioning of a long list of current drugs. Sometimes the desired biological effect comes from the selective action on a single protein, in other instances it is the combined effect on the working of several proteins. The appropriate selectivity profile is key to the safety and efficiency of the drug in both cases.

The completion of the Human Genome Project, in parallel with a significant improvement in the performance of the analytical instrumentation, increased our molecular and systemic level understanding of diseases immensely. Analysis of the differences between healthy and diseased cells and tissues led to the identification of new targets, a lot of which are not classical enzymes but proteins exerting their effect through molecular interactions with other proteins or nucleic acids. Although these proteins were considered undruggable some decades ago, their disease modifying potential led to the discovery of new approaches and modalities to target them. The inhibition of protein-protein interactions, for example, requires the selective targeting of hydrophobic surfaces, sometimes with very high affinity. Drug candidates acting through this molecular mechanism are typically beyond the size of classical drugs that might complicate their development.

Besides interacting directly with the protein of interest we might also impact its working through manipulating its quantity within the cell. Interference with the proteasomal degradation of cellular proteins, blocking its working, or hijacking it to selectively increase the degradation of our protein of choice are promising new modalities that are transitioning from research into clinical practice. Alternatively, one might also interfere with the transcriptional machinery. Selective blocking of the messenger RNA responsible for carrying the sequence information of the targeted protein by using so called antisense oligonucleotides, small interfering RNAs, or micro RNAs can result in a decreased synthesis of the protein. Appropriately designed oligonucleotides can also enhance protein synthesis or lead to an alteration of the sequence to synthesize for a given protein. Finally, we might also target the epigenetic regulatory machinery, which is in charge of unpacking the DNA double helix from its storage form and making it available for transcription. This interference typically leads to a more complex change, the parallel modulation of the level of several proteins at the same time.
\end{abstract}

Keywords: drug discovery, mechanism of action, enzyme inhibition, protein level regulation, personalized therapy 


\section{Bevezetés}

$\mathrm{Az}$ egészségünk mindannyiunk féltett kincse. Még ha megőrzésén nem is őrködünk azonos mértékben, amenynyiben betegek leszünk, úgy gyógyulásunk mind az egyén, mind a társadalom szintjén kulcsfontosságúvá válik. A gyógyszeripar elsősorban ennek a természetes igénynek, a betegségek minél hatékonyabb gyógyításának a kielégítésében vesz részt, karöltve a gyógyítást végző orvosokkal, ápolókkal. A hatékonyság és biztonságosság mint elvárások a kezdetektôl fogva megfogalmazódnak a társadalom részéról a gyógyszerekkel szemben. Ezek az elvárások különösen felerősödtek azon szerencsétlen események kapcsán, amikor a gyógyszervizsgálatok során nem sikerült egy-egy gyógyszer káros mellékhatását észrevenni és így ezek csak a tömeges alkalmazás során derültek ki. Bár az 1957-1961 között forgalmazott Contergan (thalidomide) története a legismertebb, de a jelenség már a XX. század eleje óta időról időre felütötte fejét, és a mai napig előfordul, hogy gyógyszereket kivonnak a piacról arra hivatkozva, hogy a kockázatnyereség arányuk nem megfelelő (Paine, 2017). Mielőtt azonban általánosan negatív véleményt alakítanánk ki a gyógyszeriparról, fontos megállapítani, hogy a gyógyszerkivonások jelentôs része annak tudható be napjainkban, hogy a betegségek biológiai hátterének jobb megismerésével hatékonyabb gyógymódot és készítményeket sikerült elő́llítani, melyek jobb kockázat-nyereség mutatóval rendelkeznek a régebbi gyógyszereknél. Fontos különbséget tenni a szigorú biztonsági vizsgálaton és engedélyeztetési eljáráson átmenő gyógyszerek, valamint a kevésbé szigorúan vizsgált, könnyebben forgalomba hozható gyógyhatású készítmények között is. Bár megjelenésükben nagyon hasonlítanak, és gyakran az üzletek polcain is egymás mellett látjuk ôket, de a mögöttük levô vizsgálati tapasztalat, amely hatékonyságukat és biztonságosságukat garantálná, nagyon eltérő.

Napjainkban a gyógyszerkutatási folyamat kezdeti fázisában már vizsgálják, hogy a gyógyszerjelölt molekulák a tervezett biológiai célponton kívül kölcsönhatnak-e más, nemkívánatos fehérjékkel. A sejtes vizsgálatok során szintén rutinszerúen nézik, hogy a gyógyszerjelölt fejt-e ki káros hatást olyan humán sejtvonalakra, amelyek nem részei a betegségnek. Az állatkísérletek során kiemelt hangsúlyt kapnak a gyógyszerjelölt biztonságosságát, alkalmazhatóságának korlátait megállapító kísérletek. A humán klinikai vizsgálatok elkezdésének előfeltétele a biztonságosság részletes vizsgálata több állatmodellen. A klinikai vizsgálati fázis felépítése is olyan, hogy az egyes fázisok közötti továbblépés feltétele az elvárt biztonságosság igazolása. Végezetül a gyógyszer biztonságosságának vizsgálata nem ér véget a klinikai fázisban, és az engedélyezett hatóanyagok alkalmazásának biztonságosságát is folyamatosan vizsgálják a farmakovigilanciának nevezett tevékenység keretében.

A gyógyszeripar törekvése, hogy minél hatékonyabban segítse a betegek gyógyulását. Ennek hagyományos útja a hatékony és biztonságos gyógyszerek kifejlesztése. Emellett azonban mára a pontos és érzékeny diagnosztikai módszerek felfedezése és a gyógyítás szolgálatába állítása egy hasonlóan fontos területté nőtte ki magát, amit öszszefoglalóan teranosztikának is hívunk. A diagnosztikai eljárások és eszközök segítségével nagy biztonsággal eldönthető, hogy egy adott személy esetében fennáll-e a betegség, illetve, hogy milyen eséllyel reagál várhatóan egy meghatározott kezelésre. Így lehetőség nyílik a beteg számára a megfelelő kezelés, ún. személyre szabott terápia kiválasztására, illetve elkerülhetjük az olyan kezelések alkalmazását, amelyek nem hoznának javulást. Bár a diagnosztikai eljárások ismertetése nem tárgya ennek a közleménynek, de a hatékony és biztonságos gyógyításban játszott, egyre kiemelkedőbb szerepük elvitathatatlan.

\section{A gyógyszerkutatás fóbb megközelítései: fenotípusos és célpontalapú kutatás}

A gyógyszerkutatás során két eltérő megközelítést alkalmazhatunk. Az egyik esetben egy viszonylag összetett modellünk van a betegségről, például egy állatmodell, és az egyes gyógyszerjelöltek hatását közvetlenül vizsgáljuk. Ennek az ún. fenotípusos megközelítésnek (Moffat et al. 2017) az az előnye, hogy a várt biológiai hatást egy komplex környezetben érjük el, ami biztató a gyógyszerjelölt várható hatékonyságát illetően. Ugyanakkor nem ismerjük pontosan azokat a biokémiai folyamatokat, amelyekre a gyógyszerjelöltünk hatással van, így a biztonságosságát nehezen tudjuk megjósolni.

A másik úton haladva igyekszünk megérteni az adott betegség kialakulását és fennmaradását eredményező biokémiai, rendszerbiológiai eseményeket, és ezek megértése alapján kijelölni azt a molekuláris biológiai célpontot, amelynek támadásától a betegségboól való gyógyulást várjuk (Marshall et al. 2018). A célpontalapú megközelítés előnye, hogy molekuláris szinten követni tudjuk a beavatkozásunk eredményét, és előre tudjuk jelezni a jövőbeni kezelés várható kockázatait. Ugyanakkor a célpontalapú megközelítések gyakran azon buknak el, hogy nem elég hatékonyak, mert a betegség mint komplex, élő rendszer módot talál arra, hogy ellensúlyozza a molekuláris célpont szintjén végzett beavatkozásunkat.

A 21. század komoly áttörést hozott a biológiai folyamatok megértésében. Az 1990-2003 között zajló Humán Genom Projekt eredményeként betekintést nyertünk az emberi génállományba, pontosabban megismertük annak felépítését és szabályozását, valamint a figyelmünk az addig ismeretlen fehérjék létére irányult. A technológia fejlődésének köszönhetően egy sejt genetikai állományának (DNS) az azt felépító nukleozidok szintjén történő leírása mára mind időben, mind költségben is könnyen elérhetővé vált. Ennek következtében egy adott betegségtípusban szenvedő különböző betegek és az egészséges egyének genetikai állományának összehasonlításával sokat tanultunk a különböző betegségek genetikai hátteréről. A szervezetünk múködésének és a be- 
tegségeknek a vizsgálata azonban nem állt meg a genetikai állományok, a DNS vizsgálatánál. A sejtekben a DNS-ben tárolt információ először átíródik RNS molekulákra (transzkripció), majd az RNS molekulák által hordozott információ, egy ún. érési folyamatot követően, mely során kémiai szerkezetük is megváltozik, lefordítódik fehérjeszerkezetté (transzláció). A fehérjeszintézis lezárásaként az elóállított fehérjemolekulák további „kisebb” kémiai átalakításon (ún. poszttranszlációs módosítás) eshetnek át, mielőtt képesek lesznek ellátni biokémiai szerepüket. A modern analitikai kémiai vizsgálati módszerek lehetővé teszik, hogy a sejt szintjén egyszerre vizsgáljuk a DNSben tárolt információt (genomika), a sejtben jelen levő RNS állományt (transzkriptomika), a sejt fehérjeállományát és annak kémiai módosításait (proteomika), valamint a sejtet alkotó molekulák közötti kölcsönhatásokat (interaktomika). Nem nehéz elképzelni, hogy az egészséges és beteg sejtek, szövetek szintjén végezve ezeket a vizsgálatokat milyen sokrétü betekintést kapunk a biológiai folyamatok molekuláris hátterébe. A legnagyobb kihívást talán a szinte áttekinthetetlen mennyiségű adat gyüjtése, tárolása, rendszerezése és elemzése jelenti, melyet ma már a bioinformatikára szakosodott kutatók serege támogat. $\mathrm{Az}$ adattudomány segítségével egy időben vizsgálhatjuk a biológiai folyamatok egymásra hatását, összefonódását a rendszerbiológia segítségével, és vehetjük górcsó alá egy adott beteg egy kiválasztott fehérjéjének kémiai változását a beteg sejtekben, ezáltal segítve a célpontalapú gyógyszerkutatás folyamatát.

Bár mind eszköztárunk, mind megértésünk sokat fejlődött az elmúlt két évtizedben, még messze járunk attól, hogy a sejtszintû vizsgálatok segítségével személyre szabott beavatkozási pontokat azonosítsunk (biztonságosság), és ez alapján meggyógyítsuk a betegeket (hatékonyság). Ugyanakkor a gyógyszerkutatás arra törekszik, hogy ezeket az új felfedezéseket minél hatékonyabban beépítse napi múködésébe. A következő fejezetek azt mutatják be, hogy a sejtfolyamatok különböző szintjén való beavatkozás milyen lehetőségekkel és kihívásokkal jár a betegségek gyógyításában.

\section{Régi-új megközelítések a gyógyszerkutatásban}

A bio-makromolekulák, és ezen belül a fehérjék megismerése és múködésük vizsgálata a kémia hőskorától kezdve izgatta a kutatókat. A XX. századi gyógyszerkutatás alapjait Emil Fischer 1894-ben posztulált, az enzimek múködését leíró kulcs-zár elmélete (Fischer 1894) fektette le. Elmélete szerint egy fehérje aktív centrumában (zár) az aktivitás feltétele, hogy a hozzá pontosan illeszkedő molekulával (kulcs) találkozzon, melyet az adott fehérje szubsztrátjának nevezünk. E találkozás következtében a fehérje elvégzi dolgát, például enzimként átalakítja a szubsztrátot, vagy receptorként kémiai jelet generál, míg a nem megfelelően illeszkedő egyéb molekulákkal (rossz kulcsok) való találkozás nem vezet átalakuláshoz.
A gyógyszerkutatásban a mai napig a leggyakoribb megközelítés a fehérjék múködésének befolyásolása, elsősorban a szubsztrát kötődésének gátlása. A XX. század utolsó évtizedei hozták azt a felismerést, hogy számottevő biológiai hatást érhetünk el oly módon is, ha a fehérjemolekulák közötti, sejtbiológiai szempontból jelentős kölcsönhatásokat gátoljuk. Szintén a közelmúlt kutatásainak eredménye, hogy jelentős biológiai hatást válthatunk ki akkor is, ha nem gátoljuk egy fehérje múködését, hanem a sejtben levő mennyiségét befolyásoljuk. Ez elsősorban a fehérjeszint csökkentését jelenti, amit a fehérje lebontásának serkentésével, illetve a termelésének gátlásával is elérhetünk. Ritkábban, de előfordul az is, hogy egy adott fehérje termelésének a serkentésén keresztül avatkozunk be a sejt biológiai folyamataiba. Végezetül fontos megemlíteni, hogy léteznek olyan megközelítések is, amelyek nem egy adott fehérje sejten belüli mennyiségét befolyásolják, hanem több fehérje szintjében idéznek elő egyidejü változást. A következő alfejezetek ezeket a lehetséges beavatkozási módokat mutatják be részletesebben.

\subsection{Fehérjék aktivitásának közvetlen befolyásolása (enzimgátlás)}

A hagyományos és a célpontalapú gyógyszerkutatásban is a leggyakrabban egy fehérje (enzim) aktivitását szeretnénk gátolni. Fischer kulcs-zár elméletéből kiindulva a legkézenfekvőbb megoldás, ha egy molekuláris „álkulcsot” készítünk, amely a gátolni kívánt fehérje aktív centrumába kötődik, és így akadályozza a biokémiai folyamat lejátszódását. Az ilyen gátlószereket „ortosztérikus" inhibitoroknak nevezzük. Hatékonyságuk kulcsa a megfelelően erős kötődés a fehérjéhez, amely a molekulák szintjén akár percekre, órákra is blokkolhatja a természetes szubsztrát kötőhelyét. A szervezetünkben előforduló természetes szubsztrátokra általában jellemző, hogy több fehérjéhez is képesek hasonló affinitással kötődni. Így például az ATP molekula több száz fehérje esetében mutat kötődést, amely az említett fehérjék múködésének elengedhetetlen feltétele. Ugyanígy igaz a szervezetünk hírvivőire (pl. dopamin, noradrenalin, szerotonin), hogy több receptorhoz is kötődnek változó affinitással. Ebből eredően a természetes szubsztrát kötődését utánzó ortosztérikus inhibitorok esetében felmerül a kérdés, hogy mennyire szelektíven képesek egy adott célfehérjéhez kötődni, és a többi potenciális fehérje célpontot (ún. off-targetek) elkerülni. Az ilyen hatásmechanizmusú gyógyszerhatóanyagok esetében a szelektivitás általában a biztonságosság kulcsa.

Egy fehérje aktivitását gyakran befolyásolhatjuk oly módon is, hogy nem az aktív centrumába kötődik a gyógyszerhatóanyag, hanem a fehérje egy másik pontján (ún. allosztérikus kötőhely). Az allosztérikus kötődés eredménye jellemzően a fehérje alakjának a módosulása, ami vezethet az aktivitás csökkenéséhez (allosztérikus inhibitor), vagy akár növekedéséhez is (allosztérikus akti- 
vátor). Könnyen belátható, hogy egy allosztérikus helyen kötő gyógyszerhatóanyag esetében általában jobb szelektivitást és ezáltal nagyobb biztonságosságot várhatunk. Ugyanakkor nem minden fehérjén létezik allosztérikus kötőhely, és ha van is, az erre irányuló gyógyszerkutatás kockázata nagy lehet.

A szelektív enzimgátláson keresztül ható gyógyszerek egyik klasszikus példája a görcsoldó hatású drotaverin, ami a No-Spa hatóanyaga (Mészáros-SzentmiklósiCzibula 1963). A gyógyszer a foszfodiészteráz enzimek közül a PDE IV-et gátolja, míg a rokon szerkezetű PDE III-at és PDE V-öt nem. Ennek köszönhetően bár hatásosan oldja a simaizomgörcsöt, de ugyanakkor biztonságos, mert a szívizomra nem fejt ki hatást. A XX. század másik magyar sikergyógyszerének, a Cavintonnnak a hatóanyaga, a vinpocetin ugyanakkor élettani hatását úgy éri el, hogy több különböző fehérje múködését is egy időben gátolja (Kiss-Kárpáti 1996).

A célfehérje aktivitásának fokozására példa a Servier Kutatóintézet munkatársainak nemrég megjelent közleménye (Paczal et al. 2016), melyben a glükózmolekulát foszforiláló, és így a metabolizmusában fontos szerepet játszó glükokináz enzim aktivitását sikerült fokozniuk allosztérikusan aktivátorok fejlesztésével. A kutatást nagyban segítette, hogy a fehérje, és azon belül az allosztérikus kötőzseb, röntgenkrisztallográfia alkalmazásával meghatározott, atomi felbontású szerkezete ismert volt.

A fehérjék népes családját teszik ki a sejtek belseje és a külvilág közötti kommunikációért felelős receptorok. Jellemzően a természetes ligandum kötődése következtében a receptor valamilyen kémiai jelet generál, ami lehet a membránon keresztüli anyagáramlás, vagy enzimatikus reakció is. A receptorok múködésének szabályozása alapelveiben hasonlít az enzimmúködés szabályozásához. A receptorhoz kötődő gyógyszerjelölt versenghet a természetes ligandummal a kötőhelyért (ortosztérikus), vagy kötődhet más helyen is a fehérjéhez (allosztérikus). A receptor múködését a kötődés gátolhatja (antagonista), akár a természetes ligandumtól függően vagy függetlenül, vagy felerősítheti (agonista). Mivel a szervezetben több száz receptor található, így a gyógyszerjelöltünk kötődésének a szelektivitása itt is a biztonságosság alapja.

A központi idegrendszeri megbetegedések gyógyításában elterjedt megközelítés egyes receptorok vagy receptoregyüttesek múködésének szelektív befolyásolása. A közelmúlt hazai gyógyszerkutatásának nagysikerú példája a Richter Gedeon Rt. által nemrég piacra vitt cariprazine gyógyszerhatóanyag, ami elsősorban a dopamin D2 és D3 receptorokhoz kötődik nagy hatékonysággal. Egyedi receptorkötődési profiljának köszönhető különleges antipszichotikus hatása (Laszlovszky et al. 2019).

\subsection{Biokémiai folyamatok befolyásolása fehérje- fehérje kölcsönhatások gátlásán keresztül}

A biokémiai folyamatokba való beavatkozásnak egy másik módja a részt vevő fehérjemolekulák közötti kölcsön- hatás gátlása. Bár ez a lehetőség is évtizedek óta ismert volt a gyógyszerkutatók előtt, azonban a fehérjék közötti kölcsönhatási felület kismolekulás támadása sokáig lehetetlennek tünt. Ennek oka az, hogy a fehérjék általában hidrofób felületeikkel érintkeznek, amely kevés molekuláris kölcsönhatásra nyújt lehetőséget. A XX. század végén szaporodtak el azok a kutatások, amelyek ezt a megoldhatatlannak túnő feladatot célozták meg. A fellendülésben nagy szerepet játszott a biológiai folyamatok, ezen belül a rákos megbetegedések kialakulásának és fennmaradásának jobb megértése. A legnépszerúbb célpontok is jól tükrözik ezt, mint például a p53 tumorszupresszor és a lebontását kiváltó hdm2 rövidítésû ligázfehérje (Beloglazkina et al. 2020), a tumoros sejtek életben maradásért felelős Bcl-2 fehérjecsalád tagjai és az általuk „fogvatartott”, programozott sejthalált beindító BH3 fehérjék közötti kapcsolat (D’Aguanno, Del Bufalo 2020), vagy a tumorellenes immunválasz kialakulását gátló PD-1 receptor és a PD-Ll ligandum közötti kapcsolat megbontása (Wu et al. 2021).

A fehérje-fehérje kölcsönhatás gátlásán alapuló gyógyszerkutatás kihívásait egy hazai fejlesztésű gyógyszerjelölt, a Servier Kutatóintézetből induló S64315 kódjelű molekula példáján keresztül mutatjuk be. A programozott sejthalál fontos eleme a szervezetünk beépített minőségbiztosítási rendszerének. Amennyiben egy sejt érzékeli, hogy a belső biokémiai folyamatai javíthatatlanul módosultak, lehetősége van az ún. BH3 fehérjék sejten belüli szintjének megemelésével beindítani az adott sejt programozott önpusztítását, az apoptózist. A rákos sejtek esetében is beindul a $\mathrm{BH} 3$ fehérjék túltermelése, mert a normálishoz képest jelentősen megváltozik a belső biokémiai egyensúlyuk. Ugyanakkor a rákos sejtek úgy kerülik el a programozott sejthalál bekövetkeztét, hogy fokozzák a BCL-2 fehérjecsalád egyes tagjainak (BCL-2, MCL-1, BCL- $\mathrm{x}_{\mathrm{L}}$ ) szintézisét, amelyek erôs fehérje-fehérje kölcsönhatáson keresztül megkötik, mintegy fogva tartják a BH3 fehérjéket, és ezek így nem tudják beindítani az apoptózist. A gyógyszerjelöltünk hatékonyságának kulcsa az erős fehérje-fehérje kölcsönhatás megbontása, így a gyógyszerkutatási folyamat kulcsfontosságú eleme volt a megfelelő érzékenységű vizsgálati módszerek hadrendbe állítása. A kismolekulás fragmensekből kiinduló folyamat elején a vizsgált anyagok kötődési állandója a magas mikromólos tartományba esett, ahol a vizsgálatok elsősorban az NMR-spektroszkópiára támaszkodtak (Murray et al. 2019). A kutatás kezdetén a hatékonyság növelése volt az elsődleges célunk. Az optimálási folyamat eredményeként vegyületeink kötődése jelentősen javult, így a disszociációs állandó a nanomólos koncentrációtartományba került, amihez újabb, fluoreszcens mérésen alapuló módszert vezettünk be. A kutatás eme fázisában a biztonságosság kérdése is előtérbe került. Elvárás volt az MCL-1 fehérjéhez való hatékony kötődés mellett, hogy a fehérjecsalád többi tagjához ne, vagy csak jóval gyengébben kötődjön a gyógyszerjelöltünk, így ezekhez a fehérjékhez való affinitást is folyamatosan vizsgálnunk kellett. A különböző 
fehérjékhez való kötődés erőssége és a molekuláink szerkezete közötti összefüggést megértve sikerült a kívánt szelektivitást biztosítanunk (Szlavik et al. 2019). A vezérmolekula optimálása során a kötődésünk a pikomólos tartományba került, amely egy harmadik, nagy érzékenységű módszer kifejlesztését igényelte. $\mathrm{Az}$ általunk kifejlesztett gyógyszerjelölt (S64315) hatékonyságának kulcsa, hogy az MCL-1 fehérjéhez való kötődése nagyságrendekkel erősebb, mint a kiszorítani kívánt $\mathrm{BH} 3$ fehérjéké, ami bizonyos rákos sejtvonalak hatékony pusztításához vezetett mind in vitro tesztekben, mind in vivo betegségmodellekben. Az S64315 esetében az MCL-1 rokon fehérjéihez való kötődés nagyságrendileg 100000 szer gyengébb volt, mint az MCL-1-hez (Szlavik et al. 2020).

A programozott sejthalál visszaállítását kiváltó MCL-1 inhibitorok várható biztonságosságával kapcsolatban megoszlottak a vélemények. Állatmodelleken végzett vizsgálatok azt mutatták, hogy az MCL-1 fehérje létfontosságú a magzati fejlődés és az egészséges élet szempontjából egerekben. Az eredmények alapján kétséges volt, hogy az MCL-1 gátlásának lesznek-e káros következményei az egészséges sejtekben, szövetekben. MCL1 függő rákos betegséget hordozó egereket kezelve sikerült kimutatni, hogy az MCL-1 gátló vegyületeink a rákos betegséget hatékonyan gyógyították, míg a gyógyult állatok különböző szöveteit vizsgálva nem találtak káros elváltozást bennük (Kotschy et al. 2016).

\subsection{Fehérjék mennyiségének közvetlen befolyásolása (irányitott fehérjelebontás)}

Könnyen belátható, hogy a szervezetünkben zajló biokémiai folyamatokba nem csak úgy avatkozhatunk be, ha a megfelelő fehérje múködését közvetlenül gátoljuk vagy aktiváljuk valamilyen hatóanyaggal. Hasonló eredményt érhetünk el, ha a kiválasztott fehérje sejten belüli menynyiségére gyakorolunk hatást: azt csökkentjük, vagy növeljük. A sejtjeinkben a fehérjék szintézise szabályozottan zajlik. Ahhoz, hogy a sejten belüli egyensúly fennmaradjon, a fehérjéket lebontó folyamatok is hasonlóan szabályozott múködést mutatnak. A körforgás lehetőséget ad a hibás (pl. rosszul feltekeredett) fehérjék eltávolítására, valamint a gyors reagálásra külső behatás esetén (pl. a válaszhoz szükséges fehérjék sejten belüli szintjének gyors emelésére). A fehérjék lebontása sejteken belül két fóbb útvonalon zajlik: a proteaszómális, illetve a lizoszómális úton (Martinez-Vicente-Cuervo 2007), melyek közül az első a gyógyszerkutatási szempontból jelentősebb. Az S26 proteaszóma az oda irányított fehérjéket aminosavakra bontja. Azt, hogy mely fehérjemolekulákat kell lebontani, a sejt kémiai jelöléssel, 76 aminosavból álló ubikvitin egységeknek a lebontandó fehérjére való akasztásával jelöli meg. Ezt a kémiai jelölést ún. E3 ligáz enzimkomplexek végzik. A szelektív lebontást az segíti, hogy szervezetünkben 600 feletti E3 ligáz található, melyek más-más fehérjék ubikvitilálását segítik elő (Schapira et al. 2019). A fehérjelebontás biokémiai hátterét részleteiben csak az elmúlt évtizedekben fedezték fel, de ennek kihasználása új távlatokat nyitott a gyógyszerkutatásban.

A proteaszóma múködésének kismolekulás gátlása a sejten belül a le nem bontott molekulák felhalmozódásához vezet, ami sejtpusztulást indukál. Mivel a gyógyszerhatóanyagok hasonlóan gátolják a beteg és egészséges sejteket is, így a megközelítés biztonságossága kérdéses volt. A klinikai vizsgálatok és a gyógyítási gyakorlat ugyanakkor azt mutatja, hogy a proteaszóma gátló gyógyszerhatóanyagok (bortezomib, carfilzomib, ixazomib) bizonyos rákos betegségtípusoknál a kezelés hasznos elemei lehetnek.

Az irányított fehérjelebontás mint terápiás lehetőség elterjedéséhez a proteaszómális lebontás folyamatának jobb megértése mellett egy híres-hírhedt gyógyszerhatóanyag, a thalidomide is hozzájárult. Erról a molekuláról több mint 30 évvel nyugtatóként való katasztrofális bukása után kiderült, hogy hatékonyan gátolja az érképződést és modulálja az immunválaszt, aminek eredményeképpen gyógyítja például a mieloma multipla ráktípust vagy a leprát is. Hatásának molekuláris alapja az, hogy két fontos szabályozó fehérje (ún. transzkripciós faktor), az IKZFl és IKZF3 lebomlását serkenti (Krönke et al. 2014; Lu et al. 2014). A thalidomide molekula a sejtekben a cereblon fehérjéhez kötődik, amely egy E3 ligáz. A cereblon-thalidomide komplex hatékonyan köti az IKZFl és IKZF3 fehérjéket (ellentétben a magányos cereblonnal), és indukálja ezek ubikvitinálását, ami a proteaszómális lebontásukon keresztül csökkenti a sejten belüli mennyiségüket. Bár a thalidomide és követői (lenalidomide, pomalidomide) egyes fehérjék szelektív és hatékony lebontásához és az ebből eredő biológiai hatáshoz vezetnek, ugyanakkor a hatóanyagok által lebontásra ítélt fehérjék, még ha mutatnak is szerkezeti hasonlóságot (Mészáros et al. 2017), de nem tervezhetőek előre, ami a biztonságosság szempontjából aggályos lehet.

Ideális esetben egy hatóanyag molekula az általunk kiválasztott fehérje szelektív proteaszómális lebontását eredményezné, és ezáltal gátolná a célfehérje múködését, amitől a hatékonyság mellett a biztonságosság növekedését is remélhetjük. A fehérjelebontási gépezetet kihasználó új típusú hatóanyagok legjelentősebb családja a proteolízist célzó kimérák (angol betúszavuk PROTAC). A PROTAC-ok egy E3 ligázhoz kötődő és egy, a lebontani kívánt fehérjéhez kötődő molekularészlet kémiai házasításából jönnek létre. Az összekötő molekularészlet (ún. linker) hossza és kémiai összetétele biztosítja a ligázkomplex hatékony múködéséhez szükséges térbeli közelséget a célfehérjével. A PROTAC hatóanyagok nemcsak a biokémiai folyamatokba való célzott beavatkozás révén lehetnek hatékonyak, elsősorban a rák gyógyításában, hanem az olyan betegségek esetében is, amelyek káros fehérjefelhalmozódással járnak. Így egyes központi idegrendszeri betegségek, például Alzheimerés Parkinson-kór, kezelésében áttörést jelenthetne az 
idegsejtek Tau, vagy $\alpha$-szinuklein fehérje szintjének szelektív csökkentése (Boland et al. 2018). Bár a PROTAC hatóanyagok közül néhány már klinikai vizsgálati fázisba került, ennek a hatásmechanizmusnak a mélyebb megértéséhez és a hatékonyabb kihasználásához még számos, részben alapkutatási kérdést is meg kell válaszolni.

\subsection{Fehérjék mennyiségének és minőségének befolyásolása a transzkripció, transzláció szintjén (ASO, aktiválás, génterápia)}

Egy kiválasztott fehérje sejten belüli szintjét a fehérje szintézisének a gátlásával vagy aktiválásával is befolyásolhatjuk. Mint a bevezetóben említettük, a DNS molekulák hordozzák kódolt formában az egyes fehérjék aminosavsorrendjét. A DNS-ben tárolt információ RNS-re való átírása, az RNS érése és a sejtmagból a sejtplazmába való kijutása, valamint a sejtplazmában az RNS által közvetített információ riboszóma által fehérjévé való átírása, számos beavatkozási pontot kínál (Bhat et al. 2015; Laham-Karam et al. 2020). A folyamatban részt vevő bármely enzim múködésének gátlása elvileg a fehérjeszintézis lassulásához vagy leállásához vezethet. Mennyire szelektív a kiváltott hatás? Hány különböző fehérje szintézisét gátoljuk egyidejúleg? Mivel ugyanaz a gépezet vesz részt a sejten belül az összes fehérje szintézisében, így ezeknek a beavatkozásoknak esetében fontos kérdés a biztonságosság. E kihívás ellenére nagyszámú fehérjecélpont gátlására fejlesztettek már ki hatóanyagot, különösen a rákos megbetegedések kezelésére, ahol a felfokozott fehérjeszintézis a beteg sejt túlélésének alapja.

Könnyen belátható, hogy amennyiben egy adott fehérje szintézisébe szelektíven szeretnénk beavatkozni, akkor célszerú az adott fehérje egyedi kódját hordozó hírvivô RNS (mRNS) molekulát célba venni. A nukleinsavak (DNS, RNS) esetében már egy-egy nukleotid szintjén is erôs és szelektív molekuláris kölcsönhatás alakulhat ki, ami azt eredményezi, hogy egy tetszőleges oligonukleotid szakaszhoz, például az adott RNS molekula egy részletéhez, kialakítható nagy hatékonysággal és szelektivitással kötődő, úgynevezett komplementer szál. Ennek a kötődésnek a célja általában az RNS által kódolt fehérje szintézisének a szelektív gátlása, bár célba vehetjük a fehérje szintézisének felerősítését is, vagy beavatkozhatunk az RNS érési folyamatba is, és így megváltoztathatjuk a szintetizált fehérje aminosavsorrendjét (Quemener et al. 2020). Amennyiben az általunk támadni kívánt RNS szakasz nukleotidsorrendje egyedi a sejtben, úgy a hatékonyság mellett a biztonságosság is javul. A nukleinsavszintû́ beavatkozások egyformán lehetőséget nyújthatnak a széles körben elterjedt betegségek kezelésére, vagy egyedi genetikai elváltozásokon alapuló betegségek gyógyítására is. A genomika fejlődésével ma már gyorsan és megbízhatóan fel tudjuk térképezni a betegséget kiváltó vagy fenntartó genetikai elváltozásokat, ami nagyon ígéretessé teszi a nukleinsavakat támadó hatóanyagok (ún. antiszensz oligonukleotidok, ASO) jövőbeni alkalmazását. A terület kihívásai közül a biológiai következmények jobb megértése mellett meg kell említeni, hogy az ASO molekulák gyógyszerré fejlesztése is nagyon bonyolult, mert a biológiai membránokon nem, vagy csak nagyon nehezen jutnak át (Roberts-Langer-Wood 2020).

Bár nem kapcsolódik közvetlenül az antiszensz oligonukleotid megközelítéshez, de mindenképpen említést kell tenni a hibás gén okozta betegség kezelési lehetőségeként a génterápiáról. Az elmúlt évtizedekben jelentős fejlődést mutatott e terület is, ahol a betegséget okozó gén csendesítése, szerkesztése vagy cseréje révén érhetünk el gyógyulást (Sagoo-Gaspar 2021).

\subsection{Febérjék mennyiségének szabályozása a génexpresszió szintjén (epigenetikus szabályozás)}

A sejtmagon belül a DNS-állomány kromatin formájában, fehérjekomplexként van jelen. A DNS kettôs hélix jelentős része hisztonfehérjék köré csavarodva (ún. nukleoszómát alkotva), mintegy gyöngyfüzérszerú elrendezésben található, és a nukleoszóma láncolat további feltekeredése eredményezi a kromatin szerkezetét. Ahhoz, hogy egy adott fehérje szintézise megvalósuljon, a genetikai kódját hordozó DNS szakasznak először fel kell szabadulnia, le kell tekerednie a nukleoszóma magját alkotó hiszton fehérjéről. Ennek a folyamatnak a molekuláris szintû szabályozását nevezzük epigenetikus szabályozásnak, és a benne részt vevő fehérjék is természetes gyógyszercélpontok. Az epigenetikus szabályozásba való beavatkozás eredményeképpen megváltozik a génexpressziós mintázat, ami több fehérjét is érint. Jelenlegi ismeretünk alapján még nehezen tudjuk megjósolni, hogy több fehérje sejten belüli mennyiségének az egyidejü megváltoztatása milyen következményekkel jár, ami nyilvánvaló biztonságossági kihívás. Ugyanakkor több rákbetegség esetén megfigyelték az epigenetikus szabályozás megváltozását. Ilyen esetekben a kezelés részeként törekedhetünk az egészséges sejtekben levő szabályozáshoz hasonló állapot visszaállítására, valamely epigenetikus szabályozó fehérje múködésének a gátlásával (Cheng et al. 2019).

\section{4. Összegzés és kitekintés}

A betegségek jobb megértésében, ami egyben hatékonyabb kezelésük alapja is, kiemelkedő jelentôségú változást hozott a genomika, transzkriptomika, proteomika és a bioinformatika robbanásszerú fejlódése az elmúlt két évtizedben. A célzott terápiák eszköztárának folyamatos bővülése a gyógyítás hatékonyságát növeli, míg az egyes betegek egyedi „omikai” profiljának a felállítása a biztonságosabb és hatékonyabb gyógyítás alapja lehet. Különösen igaz ez a rákos megbetegedésekre, amelyek genetikai mintázata személyről személyre változik. Bár Emil Fischer fehérjék múköoését leíró kulcs-zár elmélete a mai napig 
jól alkalmazható, a sejten belüli szabályozási folyamatok jobb megértése jelentős bővülést hozott a terápiás modalitások terén. Egy adott fehérje múködésének ortosztérikus vagy allosztérikus gátlásán, esetleg serkentésén túl beavatkozhatunk a fehérje sejten belüli kölcsönhatásaiba, növelhetjük vagy csökkenthetjük sejten belüli mennyiségét. Attól függően, hogy a molekuláris biológiai gépezet melyik lépését befolyásoljuk, várhatunk egyszerúbb és jobban tervezhető, vagy összetettebb hatást. A modern gyógyszerkutatás folyamatosan törekszik az új tudományos eredmények gyógyításban való alkalmazására. Ebben a folyamatban kulcsfontosságú, hogy az alapkutatási eredmények és a gyógyászat közötti ismeretlen terület feltérképezésében és áthidalásában minél több, alkalmazott kutatást is folytató szakember és kutatócsoport munkájára és szakértelmére támaszkodhassanak az ipari kutatóhelyek, mert csak így várhatjuk, hogy hatékonyabban és biztonságosabban tudjuk gyógyítani betegeinket.

\section{Irodalomjegyzék}

Beloglazkina, A., Zyk, N., Majouga, A., \& Beloglazkina, E. (2020) Recent Small-Molecule Inhibitors of the p53-MDM2 ProteinProtein Interaction. Molecules, Vol. 25. No. 5. p. 1211. DOI: $10.3390 /$ molecules 25051211

Bhat, M., Robichaud, N., Hulea, L., Sonenberg, N., Pelletier, J., \& Topisirovic, I. (2015) Targeting the translation machinery in cancer. Nature Reviews Drug Discovery, Vol. 14. pp. 261-278. DOI $10.1038 / \mathrm{nrd} 4505$

Boland, B., Yu, W. H., Corti, O., Mollereau, B., Henriques, A., Bezard, E., ... Millan, M. J. (2018) Promoting the clearance of neurotoxic proteins in neurodegenerative disorders of ageing. Nature Reviews Drug Discovery, Vol. 17. pp. 660-688. DOI $10.1038 / \mathrm{nrd} .2018 .109$

Cheng, Y., He, C., Wang, M., Ma, X., Mo, F., Yang, S., ... Wei, X. (2019) Targeting epigenetic regulators for cancer therapy: mechanisms and advances in clinical trials. Signal Transduction and Targeted Therapy, Vol. 4. Article 62. DOI: 10.1038/s41392-019 0095-0

D’Aguanno, S., \& Del Bufalo, D. (2020) Inhibition of Anti-Apoptotic $\mathrm{Bcl}-2$ Proteins in Preclinical and Clinical Studies: Current Overview in Cancer. Cells, Vol. 9. No. 5. p. 1287. DOI: 10.3390/ cells 9051287

Fischer, E. (1894) Einfluss der Configuration auf die Wirkung der Enzyme. II Berichte der deutschen chemischen Gesellschaft, Vol. 27. No. 3. pp. 3479-3483. DOI: 10.1002/cber.189402703169

Kiss B., \& Kárpáti E. (1996) Vinpocetin hatásai, hatásmechanizmusa [Mechanism of action of vinpocetine]. Acta Pharmaceutica Hungarica, Vol. 66. pp. 213-224.

Kotschy, A., Szlavik, Z., Murray, J., Davidson, J., Maragno, A. L., Le Toumelin-Braizat, G., ... Geneste, O. (2016) MCL1 inhibitor S63845 is tolerable and efficacious in diverse cancer models. Nature, Vol. 538. pp. 477-482. DOI: 10.1038/nature19830.

Krönke, J., Udeshi, N. D., Narla, A., Grauman, P., Hurst, S. N., McConkey, M., ... Ebert, B. L. (2014) Lenalidomide causes selective degradation of IKZFI and IKZF3 in multiple myeloma cells, Science, Vol. 343. pp. 301-305. DOI: 10.1126/science.1244851

Laham-Karam, N., Pinto, G. P., Poso, A., \& Kokkonen, P. (2020) Transcription and Translation Inhibitors in Cancer Treatment. Frontiers in Chemistry, Vol. 8. Article 276. DOI: 10.3389/ fchem.2020.00276
Laszlovszky I., Kiss B., Barabássy Á., Kapás M., \& Németh Gy. (2019) Kariprazin, egy új típusú - dopamin $\mathrm{D}_{3}$ receptort preferáló - parciális agonista atípusos antipszichotikum a szkizofrénia és primer negatív tüneteinek kezelésére. Neuropsychopharmacologia Hungarica, Vol. 21. No. 3. pp. 103-118.

Lu, G., Middleton, R. E., Sun, H., Naniong, M. V., Ott, C. J., Mitsiades, C. S., ... Kaelin Jr, W. G. (2014) The myeloma drug lenalidomide promotes the cereblon-dependent destruction of Ikaros proteins, Science, Vol. 343. pp. 305-309. DOI: 10.1126/science. 1244917

Marshall, L. J., Austin, C. P., Casey, W., Fitzpatrick, S. C., \& Willett, C. (2018) Recommendations toward a human pathway-based approach to disease research. Drug Discovery Today, Vol. 23. No. 11. pp. 1824-1832. DOI: 10.1016/j.drudis.2018.05.038

Martinez-Vicente, M., \& Cuervo, A. M. (2007) Autophagy and neurodegeneration: when the cleaning crew goes on strike, Lancet Neurology, Vol. 6. pp. 352-361. DOI: 10.1016/S14744422(07)70076-5

Mészáros B., Kumar, M., Gibson, T. J., Uyar, B., \& Dosztányi Z. (2017) Degrons in cancer. Science Signaling, Vol. 10, eaak9982. DOI: $10.1126 /$ scisignal.aak9982

Mészáros Z., Szentmiklósi P., \& Czibula I. (1963) HU150535 számú szabadalmi bejelentés, 1963.09.30.

Moffat, J. G., Vincent, F., Lee, J. A., Eder, J., \& Prunotto, M. (2017) Opportunities and challenges in phenotypic drug discovery: an industry perspective. Nature Reviews Drug Discovery, Vol. 16. pp. 531-543. DOI: 10.1038/nrd.2017.111

Murray, J., Davidson, J., Chen, I., Davis, B., Dokurno, P., Graham, C. J., ... Hubbard, R. E. (2019) Establishing Drug Discovery and Identification of Hit Series for the Anti-apoptotic Proteins, Bcl-2 and Mcl-1. ACS Omega, Vol. 4. pp. 8892-8906. DOI: 10.1021/ acsomega.9b00611

Paczal, A., Balint, B., Weber, C., Szabo, Z. B., Ondi, L., Theret, I., ... Kotschy, A. (2016) Structure-activity relationship of azaindolebased glucokinase activators, Journal of Medicinal Chemistry, Vol. 59. pp. 687-706. DOI: 10.1021/acs.jmedchem.5b01594

Paine, M. F. (2017) Therapeutic Disasters That Hastened Safety Testing of New Drugs. Clinical Pharmacology \& Therapeutics, Vol. 101. No. 4. pp. 430-434. DOI: 10.1002/cpt.613

Quemener, A. M., Bachelot, L., Forestier, A., Donnou-Fournet, E., Gilot, D., \& Galibert, M.-D. (2020) The powerful world of antisense oligonucleotides: From bench to bedside. WIREs RNA, Vol. 11. el594. DOI: 10.1002/wrna.1594

Roberts, T. C., Langer, R., \& Wood, M. J. A. (2020) Advances in oligonucleotide drug delivery. Nature Reviews Drug Discovery, Vol. 19. pp. 673-694. DOI: 10.1038/s41573-020-0075-7

Sagoo, P., \& Gaspar, H. B. (2021) The transformative potential of HSC gene therapy as a genetic medicine. Gene Therapy, DOI: 10.1038/s41434-021-00261-x

Schapira, M., Calabrese, M. F., Bullock, A. N., \& Crews, C. M. (2019) Targeted protein degradation: expanding the toolbox. Nature Reviews Drug Discovery, Vol. 18. pp. 949-963. DOI: 10.1038/ s41573-019-0047-y

Szlavik, Z., Csekei, M., Paczal, A., Szabo, Z. B., Sipos, S., Radics, G., Kotschy, A. (2020) Discovery of S64315, a Potent and Selective Mcl-1 Inhibitor. Journal of Medicinal Chemistry, Vol. 63. pp. 13762-13795. DOI: 10.1021/acs.jmedchem.0c01234

Szlavik, Z., Ondi, L., Csekei, M., Paczal, A., Szabo, Z. B., Radics, G., .. Kotschy, A. (2019) The structure guided discovery of a selective Mcl-1 inhibitor with cellular activity. Journal of Medicinal Chemistry, Vol. 62. pp. 6913-6924. DOI: 10.1021/acs. jmedchem.9b00134

Wu, Q., Jiang, L., Li, S.-C., He, Q.-Y., Yang, B., \& Cao, J. (2021) Small molecule inhibitors targeting the PD-1/PD-Ll signaling pathway. Acta Pharmacologia Sinica, Vol. 42. pp. 1-9. DOI: $10.1038 / \mathrm{s} 41401-020-0366-\mathrm{x}$

A cikk a Creative Commons Attribution 4.0 International License (https://creativecommons.org/licenses/by-nc/4.0/) feltételei szerint publikált Open Access közlemény, melynek szellemében a cikk bármilyen médiumban szabadon felhasználható, megosztható és újraközölhető, feltéve, hogy az eredeti szerző és a közlés helye illetve a CC License linkje és az esetlegesen végrehajtott módositások feltüntetésre kerülnek. 